\title{
Microfluidic Devices: A New Paradigm in Toxicity Studies
}

\section{Mikroakışkan Cihazlar: Toksisite Çalışmalarında Yeni Bir Yaklaşım}

\author{
Fatma Esra Yiğit ${ }^{1 \odot}$, Kutay İçöz ${ }^{2,3 \odot}$, iffet İpek Boşgelmez ${ }^{4 * \odot}$ \\ ${ }^{1}$ Faculty of Pharmacy, Erciyes University, Kayseri, Turkey. \\ ${ }^{2}$ Department of Bioengineering, Abdullah Gül University, Kayseri, Turkey. \\ ${ }^{3}$ Department of Electrical and Electronics Engineering, Abdullah Gül University, Kayseri, Turkey. \\ ${ }^{4}$ Department of Toxicology, Faculty of Pharmacy, Erciyes University, Kayseri, Turkey.
}

\section{ABSTRACT}

\begin{abstract}
$\mathrm{n}$ recent years, great emphasis has been placed on non-animal toxicological methods (e.g. in vitro models, in silico or -omics data) as alternative strategies to reduce animal-testing, in line with the $3 R$ (Replacement, Reduction, and Refinement) principle. These methods help in the rapid and accurate estimation of preclinical efficacy and safety associated with discovery of new drugs, and reduction of failure rates in clinical trials. Currently, the in vitro studies have been in a transformation or replacement from two-dimensional (2D) cell cultures to three-dimensional (3D) cell cultures that can mimic the physiology of tissues, organs, and organisms.
\end{abstract}

In this context, organ-on-a-chip systems have been developed by integration of 3D culture models with emerging microfluidic technologies. Since the organ-on-a-chip systems provide a good understanding of dose-response and toxicity mechanisms in drug research and development (R\&D), the impact of xenobiotics on the human body can be predicted in a satisfactory level. Besides, these systems may support assessment of pharmacokinetic-pharmacodynamic parameters as well as detection of drug resistance. Models can be generated as "disease-models-on-a-chip" or with healthy cells to the evaluate response to xenobiotic under test.

In this review, we will focus on the microfluidic systems being used in organ-on-a-chip systems and emphasize their potential for toxicity studies in which micro-environments of examples including liver, kidney, brain, lung, heart, and intestines and their physiological properties as reflected to organ-on-a-chip models.

\section{Key Words}

Microfluidic devices, organ-on-a-chip, toxicity testing, drug R\&D

\section{öz}

on yıllarda, 3R (yerine koyma, azaltma, iyileştirme) prensibi doğrultusunda deney hayvanı kullanımını azaltmak için alternatif toksikoloji metotlarına (örneğin, in vitro modeller, in silico veya -omics verilerine) büyük önem verilmektedir. Bu metotlar, yeni ilaçların keşfedilmesiyle ilişkili preklinik etkinlik ve güvenliğin hızı ve doğru bir şekilde tahmin edilmesine ve klinik çalışmalarda başarısızlık oranlarının azaltılmasına yardımcı olmaktadır. Günümüzde in vitro çalışmalar; iki boyutlu (2D) hücre kültürlerinden, doku, organ ve hatta organizmanın fizyolojisini taklit edebilen üç boyutlu (3D) hücre kültürlerine dönüşüm veya değişim içindedir.

Bu bağlamda, 3D kültür modellerinin gelişmekte olan mikroakışkan teknolojilerine entegrasyonu ile çip-üstü-organ sistemleri geliştirilmiştir. Çip-üstü-organ sistemleri, ilaç araştırma ve geliştirme (Ar-Ge) sürecinde doz-yanıt ve toksisite mekanizmalarının iyi anlaşıımasını sağladığı için, ksenobiyotiklerin insan vücudu üzerindeki etkisinin tatmin edici düzeyde tahmin edilmesi mümkün olmaktadır. Ayrıca, bu sistemler farmakokinetik-farmakodinamik parametrelerin ve ilaç direncinin değerlendirilmesini destekleyebilir. Modeller, test edilen ksenobiyotiğe yanıtı incelemek için "çip-üstü-hastalık modelleri” şeklinde veya sağlıklı hücrelerle üretilebilir.

Bu derleme kapsamında; çip-üstü-organ sistemlerinde kullanılan mikroakışkan sistemleri ele alınmakta ve karaciğer, böbrek, beyin, akciğer, kalp ve bağırsaklar gibi çeşitli örneklerin mikro-ortamlarının ve fizyolojik özelliklerinin çip-üstü-organ modellerine yansıtıldığı toksisite çalışmaları için potansiyelleri vurgulanmaktadır.

\section{Anahtar Kelimeler}

Mikroakışkan cihazlar, çip-üstü-organ, toksisite testleri, ilaç Ar-Ge

Article History: Received: Aug 25, 2019; Revised: Dec, 11 2019; Accepted: Mar 13, 2020; Available Online: May 3, 2020.

DOI: https://doi.org/10.15671/hjbc.610448

Correspondence to: I.I. Boşgelmez, Dept of Toxicology, Faculty of Pharmacy, Erciyes University, Kayseri, Turkey.

E-Mail: ibosgelmez@erciyes.edu.tr 


\section{INTRODUCTION}

Tlecu he discovery of a potential drug, i.e. finding new molecules or modified-versions of existing ones, may become "finding a needle in a haystack". Moreover, drug development may be required to provide better routes of drug delivery to the target or to obtain superior pharmaceutical dosage forms. Last but not least, for application to the approval or licensure process, the potential new drug must pass many tests, which generally begin in the laboratory moving forward to in vitro and in vivo tests and if the candidate continues to show promise, it may proceed to the clinical studies. Therefore, drug discovery, development, and approval are not only complex and time-consuming but also, they require a perfectly harmonized system and teamwork. In this context, the preclinical step, as summarized in Figure 1, may comprise in vitro human cell cultures or experimental animal testing to obtain the efficacy and safety data of the drug candidate in terms of pharmacokinetics and pharmacodynamics, drug toxicity, and treatment method [1]. However, currently available in vitro human cell culture studies may not fully reflect the complexity of living systems and may not be capable of modeling the tissue-tissue or organ-organ communica- tion. Also, they might have limited prediction capability in complex drug metabolism and the effect of metabolites on non-target tissues [2]. In addition, the animal tests are preferred because there are some difficulties in obtaining the primary cells homogeneously from the human tissue, as well as pitfalls including early aging of the cells, and the phenotypes or metabolic characteristics of the cells [3]. On the other hand, while currently accepted as the gold standard, the use of experimental animals is often costly, time-consuming, and an ethically debated process [4]. However, more critically, the findings related to drugs in experimental animals may not reflect the actual situation in humans, or may not be easily extrapolated from the test species [5].

Overall, the human body is composed of highly complex systems to perform various functions. Therefore, there is an urgent need to develop physiologically relevant, appropriate models similar to human tissues and organs for use in drug discovery and disease modeling. In this vein, recent advancements in microfluidic technologies have provided new and effective methods for providing drug research at the micro-level [6-9]. The technology resulting from these developments provides a practical solution to many of the problems associated with the

\section{The Drug Development Process}

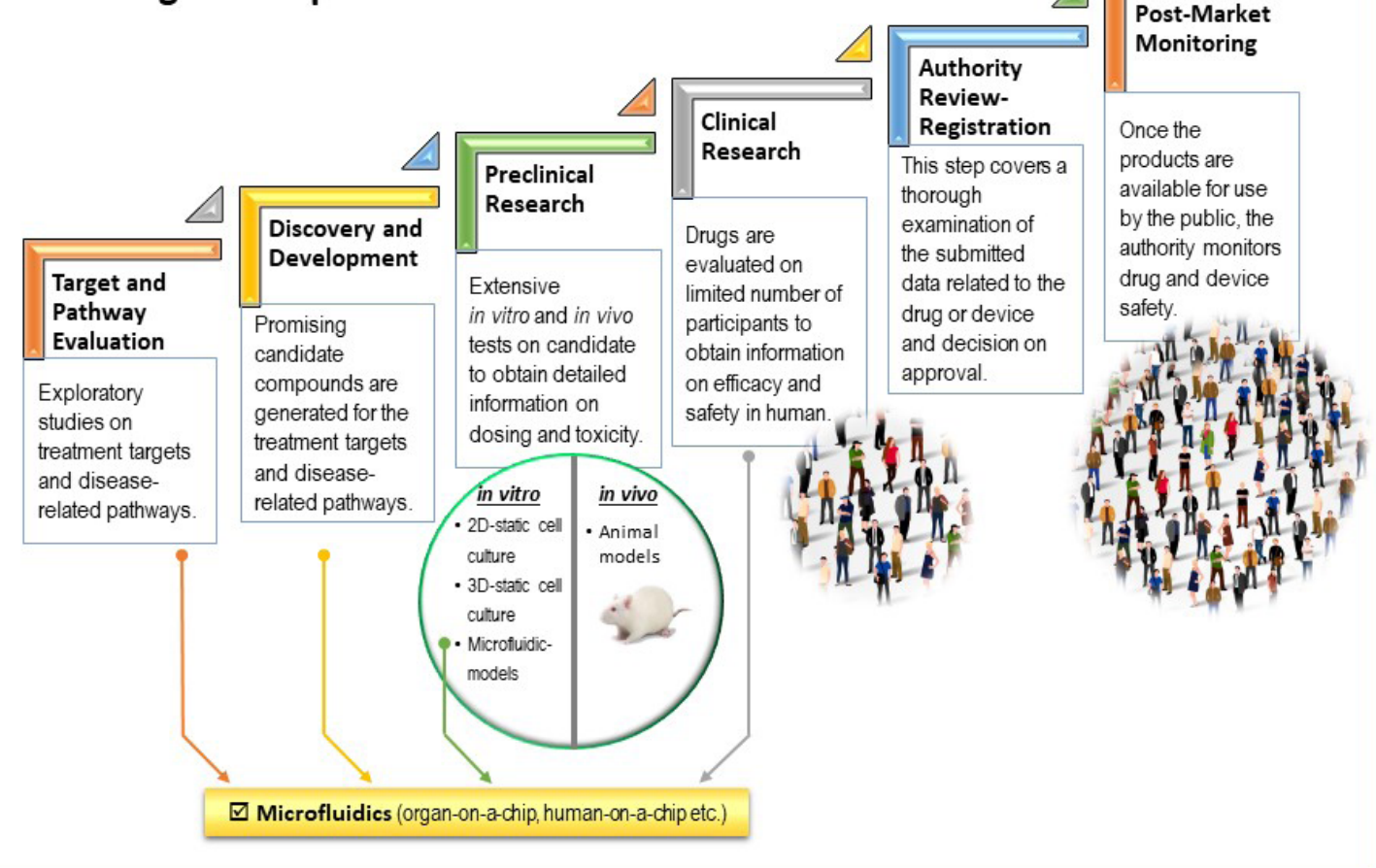

Figure 1. An overview of the drug research and development process and the role of "Microfluidics" 
above-mentioned in vitro cell culture and experimental animal use. The organ-on-a-chip systems allow a widerange of applications, including cell culture models [4]. Typical organ-on-a-chip systems are designed to perform activities and physiological responses of organs, which have controllable compartments and channels in the micrometer range, and enable the movement of small volumes of liquids or gases through these channels providing physiologically relevant conditions [3] The main motives behind this technology is to replace current tools (e.g., animal testing, 2D cell culture studies) with more specific, accurate, and high-throughput tests which can help provide a faster research period so that the drugs can enter the market earlier; moreover, the number of researched drugs are expected to increase in these settings [4]. More complex devices may include multiple cell types separated by porous layers that mimic the basal membranes of barrier tissues [1]. These multichannel chips are the focus of research by providing modeling of tissue-tissue or tissue-blood interactions and barrier functions. Barrier tissues are important in understanding the integrity and function of the barrier, the communication between tissues or tissue-blood [3]. In the last few years, liver [10], kidney $[11,12]$, lung [13], brain [14], heart [15,16], and multiorgan $[17,18]$ and disease-models [19] have been used in drug research and toxicity assessments.
The scope of this review is to emphasize the importance of research on microfluidic devices in toxicity studies by 3-dimensional (3D) cell culture applications in tissue engineering, and to compile information on recent developments for potential applications of these technologies in various areas of toxicology, especially in drug research and development.

\section{Microfluidics}

Microfluidics is briefly defined as the emerging field of engineering and application of devices that apply a controlled fluid flow in micro-scale channels. It is the science and technology of systems that process very small amounts of fluids (e.g. $1 \mathrm{~nL}$ ), using miniaturechannels (tens to hundreds of micrometers) [20]. The main concept of microfluidics is to integrate the overall laboratory into a compact micro-dimensional system. A microfluidic chip is composed of micro-channels formed generally by molding or engraving. These microchannel networks formed in the microfluidic chip are connected to the macro-environment using inlet and outlet ports with fluidic connectors of different sizes specially prepared on the chip.

A microfluidic platform serves as a consistent tool for miniaturization and parallelization of processes to be assayed [21]. Moreover, these systems provide the re-
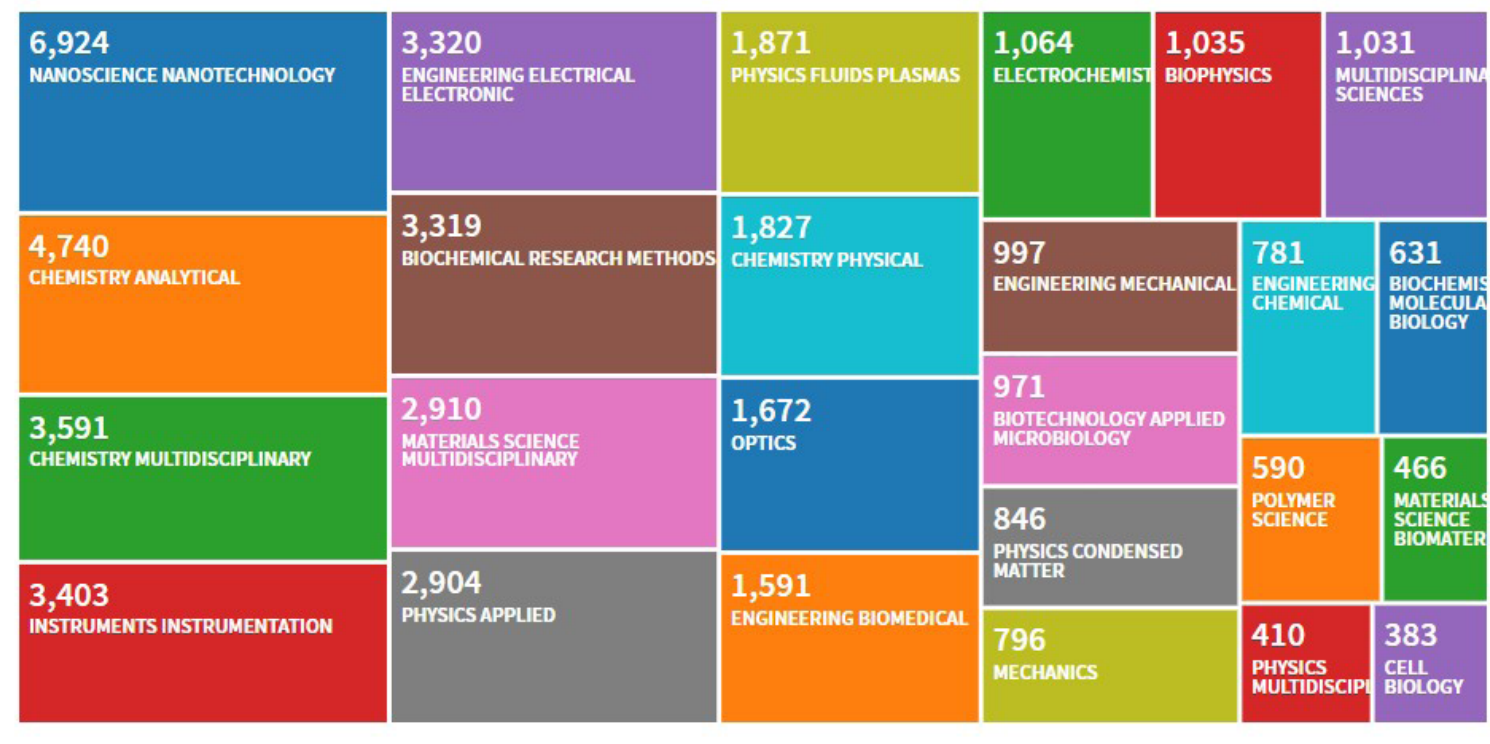

Figure 2. Distribution of top-25 "Web of Science Categories" within the published items on "Microfluidics" as of 15.01.2020. The top-5 topics are in the order of "Nanoscience-Nanotechnology", "Analytical Chemistry", "Multidisciplinary Chemistry", "InstrumentsInstrumentation", and "Electrical-Electronic Engineering". The rank of "Pharmacology Pharmacy" field is 26 "th after "Cell Biology", with 353 items, while "Toxicology" is represented in the $76^{\text {th }}$ rank with 41 items. 
quired platform for the integration and automation of multiple assays, and also, they facilitate imaging and tracking of tests or conditions. The historical evolution and diverse aspects of microfluidic systems have been reviewed in detail elsewhere $[20,21]$.

This technology may be applied to diverse areas including an increasing number of engineering fields, chemistry, life sciences, forensics, and more recently in health-related studies [22-25]. Microfluidic chips have found application areas such as drug R\&D, disease modeling, and toxicity research. There are many examples realized with microfluidic chip platforms such as signal amplification [26], capturing targets using affinity and size-based separation via antibody-conjugated magnetic beads [27], and detection of rare mutations [28]. As shown in Figure 2, the distribution of "Web of Science Categories" within the published items on the topic "Microfluidics" reveals that the top-5 topics are in the order of "Nanoscience-Nanotechnology", "Analytical Chemistry", "Multidisciplinary Chemistry", "Instruments-Instrumentation", and "Electrical-Electronic Engineering". While the rank of "Pharmacology Pharmacy" field, with 353 items, is $26^{\text {th }}$ after "Cell Biology"; currently "Toxicology" is represented in the $76^{\text {th }}$ rank with 41 items. In this sense, an interesting review by Sackmann et al. [29] underlines the fact that the majority of publications related with microfluidics are published in engineering journals (85\%), whereas the biology and medicine journals could take some publication share from interdisciplinary journals $(9 \%$ and $6 \%$, respectively).

\section{Materials in Conventional Microfluidic Platforms}

Since microfluidic technologies have found use in different applications with expanding demands that increase day by day, the selection of materials has a strong impact on the performance of the devices. Once chemicals or biological materials (e.g., proteins or cells) enter a microfluidic device, the characteristics of the material may impact the outcome [30]. As also shown in the historical timeline of developments in materials used in microfluidics [31], obviously, the synergistic innovation of materials and microfluidic platforms plays a critical role in the sophisticated and sustainable implementation of microfluidics-based technologies in various disciplines. Thus, on the one hand innovative materials serve for the emerging applications of microfluidics, on the other hand microfluidic systems provide robust and flexible platforms for the fabrication of materials with superior characteristics. Comprehensive studies which include reviews by Berthier et al. [32], Ahadian et al. [33], Zhang et al. [34], and Nielsen et al. [35] have summarized the materials used in microfluidics. Specifically, the comparative strengths and limitations of materials available for microfluidic cell-based device fabrication has also been covered in detail [32], in view of the ability to fabricate the microsystems, and to perform controllable cell-based experiments, as well as the potential for integrated micro-engineering applications.

The selection of microfluidic chip materials serves the aim to fabricate a micro-scale chip that is functional, low-cost, and portable. In other words, the main concerns in commercialization are ease of fabrication, reliability, ease of adoption by the end-user, and cost. In this sense, as briefly summarized in Table 1, there are different types of materials such as inorganics, elastomers, plastics, hydrogels, paper, hybrid and composite materials [36].

For microfluidic devices used in cellular analysis, there is often a need for a material in which the micro-channels are embedded to be porous (for exchange of nutrients, $\mathrm{CO}_{2}, \mathrm{O}_{2}$, etc.) to allow the cells to communicate with the external environment [37]. In general, hydrogels are considered suitable materials, since pores can be adjusted via thermal or electrical manipulations. Essentially, the choice of a suitable material for any type of microdevice depends on the microfluidic test applied. As a result of new microfluidic device applications and increasing demand for more flexible and advanced functionality, the range of materials applicable to microfluidic systems is continually expanding. The most commonly used substrates today include silicone, glass or quartz and polymers [37].

The microfluidic systems are generally produced from transparent polymeric materials, since this feature enables a user-friendly tracking or testing. In the late 1990s, with the concept of using polymer materials in microfluidics, the use of silicon and glass materials has shifted to polymers. Compared to silicon and glass, polymers are low-cost materials and feature a wide variety of properties to meet diverse application demands in disposable biomedical microfluidic devices, as well as various promising applications [38]. In general, elastomers (e.g. polydimethylsiloxane, PDMS) and plastics (e.g. polymethylmethacrylate, PMMA) are utilized (Figure 3). 
F.E. Yiğit et al. / Hacettepe J. Biol. \& Chem., 2020, 48 (3), 245-263 $\mid 249$

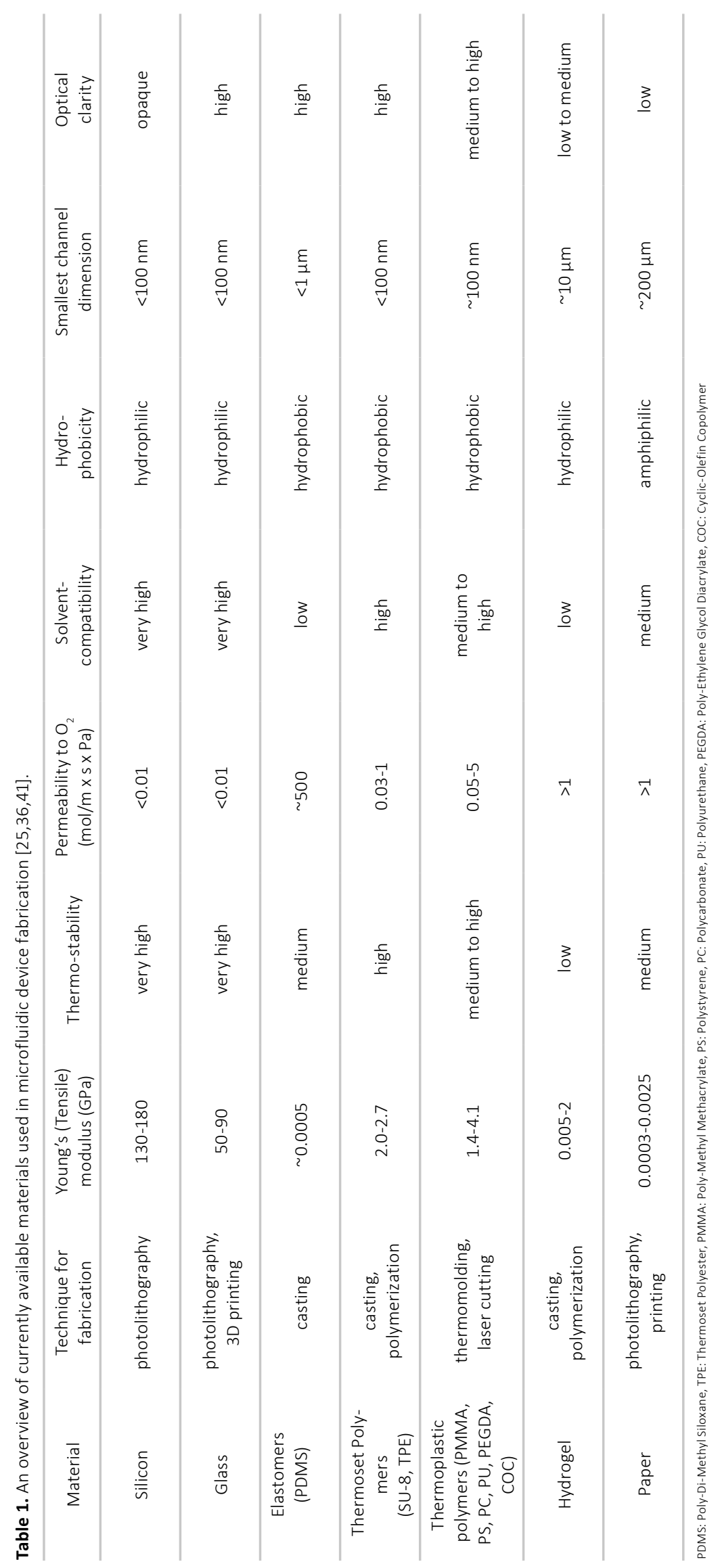



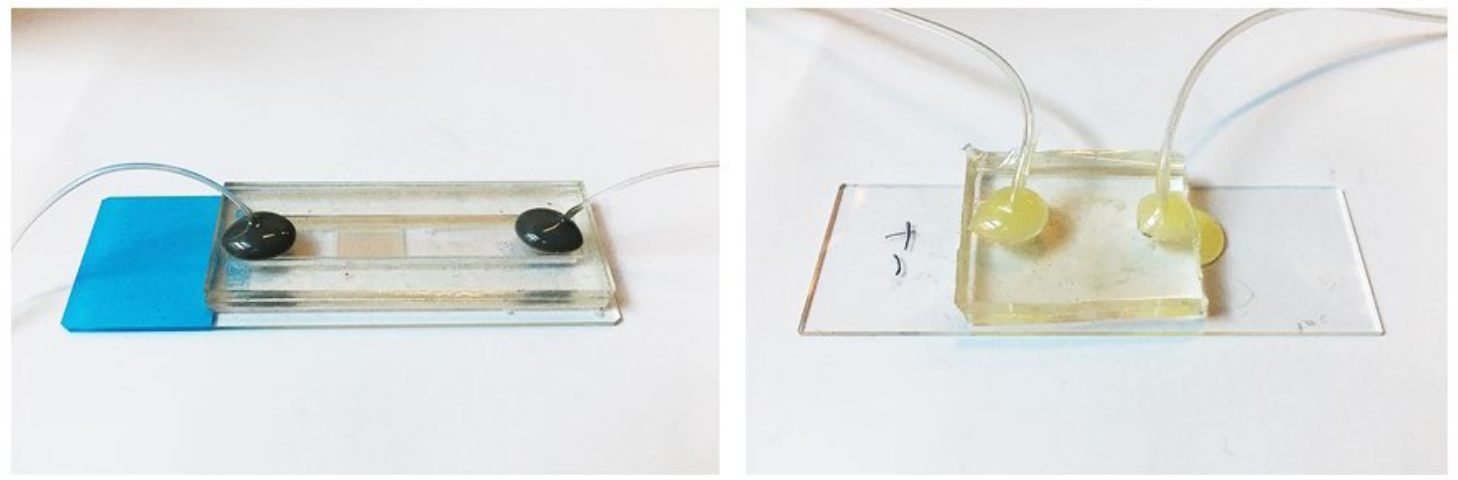

Figure 3. Two examples of microfluidic platforms. Left: A glass bottom and PMMA middle and top cover. In the channel, gold coated micro-arrays were designed for capturing cells and imaging. Right: A glass bottom and PDMS top layer, in the channel, micro posts were designed to filter out cells based on size.

Conventionally, microstructures can be manufactured by either casting, injection-molding or thermal-molding [39]. All of these methods are based on repeated use of a mold containing the prefabricated negative pattern of the final microstructure. A similar process is widely used for mass production of polymeric products, whereby the production costs of devices made of polymers are much affordable as compared to other materials. High aspect ratio and complex microstructures can be easily obtained from these materials [40]; however, the quality of the mold is critical.

The main limitations in the use of polymers are based on their relatively poor surface properties and compatibility problems with organic solvents. However, by understanding the concept of surface modification and unique surface properties (e.g. surface charge, hydrophobicity), functional surfaces can be obtained on different substrate materials by selecting suitable methods and reagents for modification [42]. A recent example is the application of a biodegradable-polymer as the base-material for the production of micro-devices with embedded microfluidic networks similar to microvascular systems, extending the application area to tissue engineering [43]. Similarly, Ogilvie et al. [44] have fabricated the channels using micro-milling and demonstrated that exposure of the polymers to an appropriate solvent vapor (chloroform for PMMA, cyclohexane for $\mathrm{COC})$ reduced the surface roughness significantly. The re-flow of polymer when exposed to a solvent vapor has also been shown to reduce the surface roughness (from $200 \mathrm{~nm}$ to $15 \mathrm{~nm}$ ). This novel surface treatment method may complement other rapid fabrication techniques for low-cost and high-quality microfluidic prototyping. In order to determine the best solvent mixture, Faghih and Sharp [45] have used solvent-based bonding with different solvent mixtures, curing times and temperatures. The results have shown that bonding strength and optical clarity have been improved when corona surface treatment was applied just before the solvent.

PDMS is probably the most preferred material in today's microfluidic devices due to several advantages. The first use of PDMS in microfluidic devices was described by Whitesides et al. (2001) [46]. PDMS has been shown to be a strikingly versatile material that enables a variety of new functions and applications in microfluidics. An interesting property of PDMS is its elasticity [37]. For example, multi-layer fluidic structures can be produced from PDMS; for this process, a small force that causes the deformation of a fluid channel is first applied for a short time, which can act as active valves or pumps [47]. Apparently, the most important issues in biological applications in microfluidic platforms are biocompatibility and cell viability. In this context, its low toxicity, high permeability to $\mathrm{O}_{2}$ and $\mathrm{CO}_{2}$, and excellent optical transparency, make PDMS a suitable material in the production of micro-channels for both proliferation and survival of the cells in optimum conditions and for technical observation [20]. In principle, PDMS is biocompatible (nontoxic to tissues and does not have harmful effects); it shows low autofluorescence and is inexpensive [48]. This material can be readily formed using PDMS molding; thus, there is no limit in the design of device [49]. On the other hand, PDMS can absorb small hydrophobic compounds [50]. Since 
hydrophobic drugs and fluorescent molecules tend to spread to PDMS walls of microfluidic devices, the concentration decrease in solution may affect the accuracy and reliability of analyzes [51]. In other words, if PDMS absorbs and retains the active substance in test, it may not be possible to detect the potential toxicity due to the unexpected concentration decrease [49]. In a study in which four cardiac drugs were tested on the PDMSbased chip, and drug absorption of the PDMS material was measured by HPLC, the absorption was shown to be variable and time-dependent and not as determined by hydrophobicity as previously claimed. The presence of two commercially available lipophilic coatings and cells appeared to affect absorption [52]. However, the investigation of the adhesive properties of the cells on a chip showed that it had no negative effect on cellular conditions and cellular behavior. PDMS-based microfluidic systems have been shown to maintain the normal cell viability for several weeks. The biocompatibility of microfluidic systems based on PDMS, and other materials such as silicon oxide and glass, was investigated and showed good cell viability [53].

Some alternative thermoplastics including polystyrene, polycarbonate, and PMMA are also available, and these materials are both optically transparent and less absorbent than PDMS [54]. Besides obtaining the desired specifications with sufficient quality to ensure the functionality, a major key factor is the selection of appropriate fabrication method, considering the overall cost of the method, including equipment, operational, and production costs, as discussed by Guckenberger et al. [55]. In an effort to make microfluidic research more accessible and cost-effective, thermoplastic materials have gained interest as an alternative to conventional materials, particularly for commercial applications. Thermoplastic materials offer a number of advantages with respect to PDMS molding for rapid, low-cost microfluidics due to their better mechanical properties, hydrophilicity and versatility in design and fabrication [56]. Being composed of linear and branched molecules, the thermoplastic materials are durable against temperature and pressure changes and they resist structural breakdown. These materials have good physical and chemical characteristics (e.g., low electrical conductivity and high chemical stability), and they are cost effective for mass production. Thermoplastics can be softened and made to flow by applying heat and pressure. During cooling, the polymer hardens and without any chemical alteration it takes the shape of the container or mold. Low cost fabrication methods for high-throughput production of microfluidic systems can be successfully achieved using thermoplastics [57]. In addition, the laser cutting method is available for polystyrene and PMMA to create layers of microfluidic devices [58]. In a recent study, Day et al. presented injection molded open microfluidic inserts fabricated from polystyrene, to use with standard cell culture well plates that allow control of evaporation and enable high resolution imaging for cell cultures. These microfluidic inserts developed for cultures suitable for mass production and have been tested with samples including culture of primary testis cells from surgical patients [59].

Recent improvements in microfluidics, with advancements of soft-lithographic and micromachining techniques in the last couple of decades, have allowed the development of versatile platform technologies providing cost-, labor-, and time-efficient operation with small volumes of reagents and samples [60]. In a microfluidic platform integrated with micro-gas exchanger capable of imposing various physiological conditions, such as flow and hypoxia, in a closed system, an approach minimizing the cost of materials and complexity in design and manufacturing of microfluidic channels with precise oxygen tension control has been presented [61]. To benefit the advantages of different materials and fabrication methods, microfluidics systems are composed of hybrid materials [62]. A viable option especially for small hydrophobic systems is the use of glass-based systems that limit the absorption in cell-based assays [63]. The paper is generally highly preferred for commercial disposable biological assays, while it may be incorporated into a hybrid chip to take advantage of the above-mentioned materials. Thus, combinations can be created based on the desired functions [36].

Manufacturing techniques for microfluidics can be divided into three categories: subtractive (etching), additive (also known as 3D printing), and molding (also known as formative). Photolithography can be defined as the process of transferring specified geometric shapes on a mask to the surface of a silicon wafer. Digital manufacturing (additive or subtractive) is a very good case study for improving fabrication processes [64]. The state-ofthe-art three-dimensional (3D) printing technology can offer a good alternative to the production of biochips [65], especially in conjunction with computer-aided designs. Since printing takes place layer-by-layer, sensors and mechanical parts can be inserted into the chip 
at any point or position. Because of the low material cost, it is considered suitable for routine and practical use in drug R\&D studies [49]. However, this technology is in its infancy and there are many aspects that need to be developed [66]. For instance, a 3D hollow micro glass structure is difficult to produce with $3 \mathrm{D}$ printing, because the materials used during production block the hollow parts. Kotz et al. (2019), developed a new technique to prevent clogging of hollow parts and with this new technique, they produced the glass chip using three-dimensional printers [67]. In the microfluidic device fabrication, it was suggested that the emerging use of advanced additive manufacturing technologies, including 3D-printing, may provide better opportunities in many applications. For example, Alapan et al. [62] have presented a novel hybrid manufacturing technique that combines 3D printing and laser micromachined lamination for complex 3D microfluidic device fabrication. In this hybrid technique, the assembly of 3D printed parts together with laser micromachined layers via lamination approach has been shown to offer a cost- and labor-efficient fabrication of standardized microfluidic discrete elements and modules. As an alternative to lithography, lamination-based fabrication approaches are becoming prevalent, in which a laser micromachined layer is sandwiched between a 3D printed layer and a glass surface, forming channels in micrometer scale (50-500 $\mu \mathrm{m})$. Lamination method offers numerous advantages over lithography, including simple manual assembly, use of off-the-shelf materials, cost-efficient fabrication, disposable usage, and operation by minimally trained personnel.

For more details, we refer to several comprehensive reviews on specific topics including the state-of-the-art in micro and nanoscale devices with highlight to major platform technologies, namely microcantilevers, micro/nanopillars, and microfluidics [68], hydrogels [69], paper-based systems [70], and emerging terms such as "Pharm-Lab on a Chip" [71]. In addition, several fields including forensic sciences have adopted use of microfluidic devices, such as in the tests of controlled substances (e.g., methamphetamine, amphetamine, cocaine, and oxycodone) [72], in the estimation of the post-mortem interval using paper-based analytical devices at crime scenes [73], and as presumptive tests in fast, simple and simultaneous screening of four biological fluids at crime scenes [74].

\section{Organ-on-a-Chip Systems and a Brief Overview on Applications in Toxicology}

An "organ-on-a-chip" is a microfluidic device designed to obtain a functional unit in which the selected cells of the organ are cultured in a continuously-perfused, small-sized (micro or nano) chamber-system to simulate the physiological conditions [1]. An example of an organ-on-a-chip system is depicted in Figure 4. This system includes interconnected four compartments to model the four human tissues: intestine, liver, skin and kidney.

One of the major challenges for the pharmaceutical industry appears as the safety issues that become evident during the post-market phase. In recent years, the main safety concerns regarding drugs seems to be related with- but not limited to- cardiac, renal, and hepatic toxicities which can lead to serious adverse reactions, even to life-threatening consequences and death. Such an alarm may end up with the withdrawal of the drug. Therefore, it is extremely critical to identify the toxic effects in an early phase in order to prevent long-term consequences. For this purpose, the development of rapid and highly accurate toxicology assays and models has become a strategic issue for the pharmaceutical industry [75]. As depicted in Figure 1, prior to clinical trials, there are preliminary studies to establish a safe dose. In drug toxicity studies, the availability of microfluidic devices may provide a great advantage in these steps [76].

As described earlier, experimental animals have long been in use to provide a systemic view since they offer strictly-controlled models similar to human physiology; however, they have some limitations. Besides ethical concerns, several real-life examples, including drug safety issues, have shown that these models may not accurately reflect or predict the actual consequences in human, due to species differences. In need of a standardized platform that mimic the "human" within an "in vitro" environment, the researchers started to develop models with high-throughput characteristics, that are less time-consuming, more feasible, and also controllable.

In this context, the earlier applications adopted conventional cell culture models that are typically performed in two dimensions (2D) using flat cell culture plates; thus, 2D cell culture applications, although consisting of human cell lines, still could not completely simulate 
a)

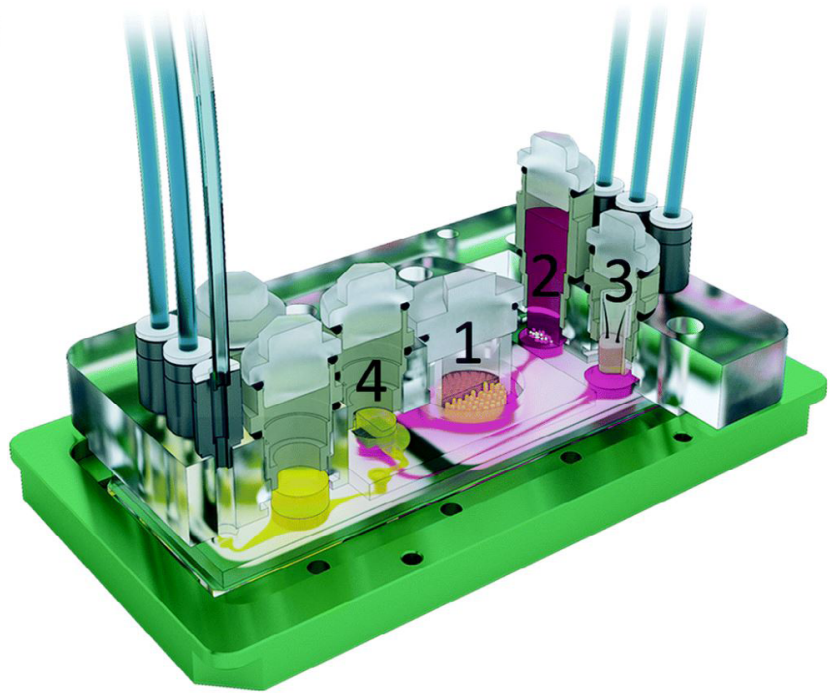

b)

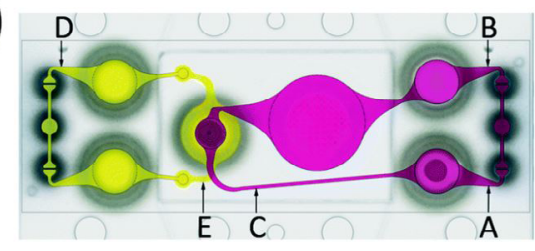

C)

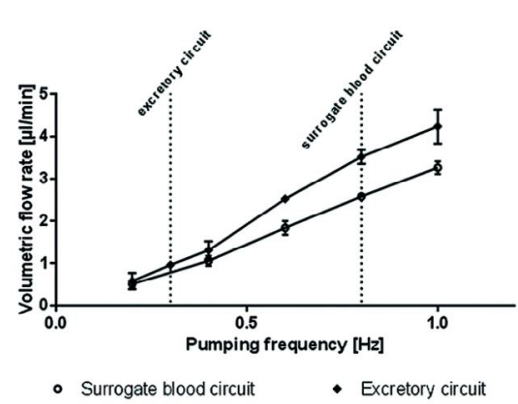

Figure 4. A multi-organ-on-a-chip device comprising four organs [17].

a) The 3D view of the device comprises two polycarbonate cover-plates, the PDMS-glass chip (footprint: $76 \mathrm{~mm} \times 25 \mathrm{~mm}$; height: $3 \mathrm{~mm}$ ) accommodating a surrogate blood flow circuit (pink) and an excretory flow circuit (yellow). The culture compartments are numbered as (1)intestine, (2)liver, (3)skin, and (4)kidney. A central cross-section of each tissue culture compartment aligned along the interconnecting microchannel is depicted.

b) The fluid dynamics in device: Top view of the four-organ-chip layout illustrating the positions of three measuring spots (A, B and C) in the surrogate blood circuit and two spots (D, E) in the excretory circuit.

c) Average volumetric flow rate plotted against pumping frequency of the surrogate blood flow circuit and the excretory circuit. Reprinted with permission from Ref[17] Copyright@ 2015 The Royal Society of Chemistry.

the required complex nature of model tissue and disease processes [77]. This can be briefly explained by the fact that the 2D cell cultures lack the components which are available "in vivo", including the complex and information-rich environment with extracellular matrix components, mixed cell populations, diverse interactions, and cell-secreted factors [78].

In order to overcome this limitation, 3D culture systems that allow better reflection of the properties specific to complex tissues have been developed by means of tissue engineering [79]. In the last decade, the use of 3D culture models has been in rise, especially to increase the similarity to in vivo. Briefly, the 3D cell culture is created in an artificial environment where cells are allowed to grow and interact with their environment in three dimensions. The organization within 3D culture systems provides a more realistic and physiologically relevant micro-environment, allowing various cellular interactions $[49,80]$. In addition, creating 3D-printed in vitro tissue models is advantageous for well-preserved tissue functions and long-term culture; however, this option also comes with its own challenges, including the insurance to sustain regular liver cell functions for more than 30 days [81], high variability in the size of the organoids as well as the difficulty of retaining the cells in consistent positions in these structures for required durations [1].

To this end, 3D cell culture applications are of interest, since they help to produce more realistic models of organ-on-a-chip [82]. The environment in microfabricated systems mimics those found in vivo. Most importantly, the microfluidic devices can be designed to resemble the cellular structures and traffic inside the human body, chemical environment can be organized to mimic the complex and dynamic 3D network, the materials used for fabrication of microfluidic devices are often compatible with the required conditions and processes such as $\mathrm{O}_{2}$ and $\mathrm{CO}_{2}$ gas exchange, nutrition, moisture, removal of metabolites, thus enable better growth and proliferation of cells in 3D culture, the devices offer a multifaceted technology handling various processes such as culture, replenishment of medium, cell detachment, sampling, mixing, capture, and detection; moreover, the use of nanoliter volumes of samples and reagents makes the system very cost effective [83]. Kwak et al. developed microfluidic platforms using 2D 
and 3D cancer cell cultures, and reported that while $2 \mathrm{D}$ models are easy to use and reproduce, 3D models have been preferred to eliminate the cellular difference in drug resistance resulting from differences in tumor microenvironment [84]. In an approach to investigate the efficacy of photodynamic therapy, Zuchowska and colleagues have used microfluidic culture models based on spheroids consisting of a co-culture of cancer and non-malignant breast cells [85], and also in 3D lung spheroid cultures [86].
In general, monitoring organ-on-a-chip systems appears to be a typical challenge. Zhang et al. have developed an automated modular physical, biochemical, and optical sensing platform, interfaced with a multi-organon-a-chip system. In an uninterrupted and automated manner, this platform monitors microenvironmental parameters (e.g., $\mathrm{pH}, \mathrm{O}_{2}$, temperature), measures soluble biomarkers via electrochemical immunobiosensors, and observes morphology using miniature microscopes. The system has been used to monitor acetaminophen-

Table 2. A brief overview of some microfluidics-related studies on toxicity/drug testing

\begin{tabular}{|c|c|c|}
\hline Organs & Details & References \\
\hline \multirow{6}{*}{ Liver } & $\begin{array}{l}\text { The decellularized liver matrix-based liver tumor-on-a-chip } \\
\text { and its application for drug toxicity testing }\end{array}$ & Lu et al., 2018 [10] \\
\hline & $\begin{array}{l}\text { Investigation of drug interactions in encapsulated } \\
\text { hepatocytes in 3D micro tissues }\end{array}$ & Li et al., 2014 [93] \\
\hline & $\begin{array}{l}\text { Characterization of toxicity of various compounds using } \\
\text { liver co-culture and smart-scale analysis }\end{array}$ & Shintu et al., 2012 [94] \\
\hline & $\begin{array}{l}\text { Testing the effects of ethanol-induced toxicity on liver } \\
\text { sections }\end{array}$ & Hattersley et al., 2011 [95] \\
\hline & $\begin{array}{l}\text { Investigation of drug metabolism using liver and intestinal } \\
\text { sections }\end{array}$ & van Midwoud et al., 2010 [96] \\
\hline & 3D HepaTox Chip preparation for hepatotoxicity testing & Toh et al., 2009 [97] \\
\hline \multirow{4}{*}{ Kidney } & $\begin{array}{l}\text { Screening drug-transporter interactions and toxicity in 3D } \\
\text { microfluidic proximal tubule epithelial cells model }\end{array}$ & Vriend et al., 2018 [11] \\
\hline & $\begin{array}{l}\text { Exposure to nephrotoxic cisplatin in a microfluidic system } \\
\text { of renal proximal tubular epithelial cells }\end{array}$ & Vormann et al., 2018 [12] \\
\hline & $\begin{array}{l}\text { Exposure to fluid flow to investigate nephrotoxicity and } \\
\text { establish its function }\end{array}$ & Jang et al., 2013 [98] \\
\hline & $\begin{array}{l}\text { Testing the effects of drugs on a dynamic kidney } \\
\text { microfluidic chip }\end{array}$ & Baudoin et al., 2007 [99] \\
\hline \multirow[b]{2}{*}{ Brain } & Drug permeability test through blood-brain barrier & Yeon et al., 2012 [100] \\
\hline & $\begin{array}{l}\text { Permeability of atenolol, caffeine, cimetidine, hydroxyzine, } \\
\text { prazosin, propranolol, trazodone tested in a model of the } \\
\text { blood-brain barrier }\end{array}$ & Shayan et al., 2011 [101] \\
\hline \multirow{2}{*}{ Heart } & $\begin{array}{l}\text { The in vitro effect of isoproterenol on electrically- } \\
\text { stimulated cardiac microtissues (within heart-on-a-chip) } \\
\text { was tested. }\end{array}$ & Agarwal et al., 2013 [102] \\
\hline & $\begin{array}{l}\text { A drug dose-response experiment was performed by } \\
\text { applying epinephrine in a heart-on-a-chip design developed } \\
\text { for in vitro cardiac contraction and pharmacological studies. }\end{array}$ & Grosberg et al., 2011 [15] \\
\hline \multirow{3}{*}{ Lung } & $\begin{array}{l}\text { Modeling of the nasal epithelium for formaldehyde toxicity } \\
\text { testing }\end{array}$ & Wang et al., 2014 [13] \\
\hline & $\begin{array}{l}\text { Modeling of disease functions by means of a chip } \\
\text { undergoing cyclic mechanical stress }\end{array}$ & Huh et al., 2012 [19] \\
\hline & $\begin{array}{l}\text { The cellular response and resistance to anticancer drug } \\
\text { were tested. }\end{array}$ & Siyan et al., 2009 [103] \\
\hline \multirow{2}{*}{ Intestine } & $\begin{array}{l}\text { Creation of a microfluidic chip model to examine the } \\
\text { gastrointestinal tract and estimate drug toxicity }\end{array}$ & Mahler et al., 2009 [90] \\
\hline & $\begin{array}{l}\text { Testing the permeability of the drug in the intestinal } \\
\text { epithelial cell membrane by micro-hole trap }\end{array}$ & Yeon et al., 2009 [104] \\
\hline
\end{tabular}


induced organ toxicity in a liver-and-heart-on-a-chip platform and also liver-cancer-and-heart-on-a-chip platform challenged with doxorubicin [87].

The organ-on-a-chip systems developed for drug screening and development purposes and their main advantages over the conventional methods were summarized, and it has been emphasized that these platforms provide more accurate models closer to native tissues [88]. As shown in Table 2, we listed some organ-on-achip systems that display the expected outcomes, with promising results. The liver is the main organ where drugs are metabolized and is therefore a common target for drug-induced toxicity, presenting a hot-topic in this field. Since the liver is susceptible to a wide range of diseases, relevant systems to test the potential hepatotoxic xenobiotics are of highest interest [89]. Hepatic phenotypes and functionality are lost due to the rapid differentiation of 2D liver cell cultures, and 3D cell culture systems more accurately reflect physiology; therefore, various 3D culture strategies are still under development and in optimization phases. In many of these models, hepatocytes retain their phenotype for a long time. It also provides an opportunity to investigate the potential of newly developed chemicals to cause chronic hepatotoxicity. Mahler et al. (2009) have utilized a model of gastrointestinal tract organ-on-a-chip system to test the impact of oral acetaminophen overdose. As the concentration of acetaminophen increased, the levels of glutathione and liver cell viability were reduced, which indicate the organ-specific effects caused by the hepatotoxic metabolite of acetaminophen [90]. Another point is the complex interaction between hepatocytes and immune cells: In the future, the development of more integrated culture models to investigate immunotoxicity may also be possible [91].

Antibiotics can lead to several side effects, including nephrotoxicity and hepatotoxicity. Since the effects of antimicrobials on mammalian cells require extensive studies, as well as the urgent need for inexpensive, fast and accurate tools and techniques that can help in the discovery and development of new antimicrobial drugs, a viable tool is required. In this sense, microfluidic devices are considered to be an excellent option to facilitate the evaluation of antibiotic activity and focus on recent developments of microfluidic devices for rapid antibiotic susceptibility testing. Two microfluidic systems have been developed in order to facilitate the evaluation of the side effects of antibiotics and the toxicity of the drug on human tissues in the treatment of infections. The first one is a cell-on-a-chip system that provides cytotoxicity information in the testing of drug candidates (e.g., mechanism of action, dose-response). The other is an organ-on-a-chip system that provides pharmacokinetic and toxicological information required in drug development [92].

Another representative example is the respiratory system. The upper respiratory tract acts as the first line of defense against many air pollutants. Finger-like protrusions called cilia located on the mucous membrane are moved back and forth when irritated, and this coordinated movement is critical to help detoxify xenobiotics in exposure via inhalation. A model which simulates this specific protective mechanism, in which human nasal epithelial cells are integrated, has been used to evaluate the toxicity of formaldehyde in gas phase transmitted by air [13]. A lung-on-a-chip system was described in [105] is a microphysiological system that replicates the functional unit of the living human lung. The microdevice includes a poly(dimethysiloxane) membrane so that mechanical stretching can be applied to adherent cell layers mimicking human breathing. In this context, Hiemstra et al. have reviewed the current literature and suggested that in view of the rapid developments in 3D culture of primary epithelial cells, generation of lung epithelial cells from induced pluripotent stem cells and organ-on-a-chip technology, these state-of-the-art models designed for evaluation of inhaled toxicants is expected to offer an alternative or complementary to animal exposure studies [106].

Since organs function within an orchestration in the body, encompassing a vast complex of networks, the generated microfluidic systems are expected to simulate the physiological conditions. Organs in the human body are often interconnected by complex biological mechanisms. There is a strict communication between different organs and tissues by networks. Mimicking the biological mechanisms of the human body requires the development of a model that mimics multiorgan interactions. How multiple organs respond to drugs is an extremely critical issue that can affect the efficacy and toxicity of drugs. Multiple organ models allow the examination of the linkage between different organs to better evaluate the safety and efficacy of a compound [107]. A number of organ-specific toxicity models are available; however, drugs may interact with multiple tissues/organs in the body, causing a complex overall response [108]. 
In Table 3, we summarized some multiple-organ-on-achip examples that provide a snapshot of microfluidic platforms with promising results.

Similar to these examples, Oleaga et al. (2016) used a chip system comprising four organ systems (liver, heart, nerve and muscle) in which a continuous flow of a serum-free environment was achieved in order to evaluate multi-organ toxicity. The effects of electrical and mechanical respon- ses to five drugs (doxorubicin, valproic acid, acetaminophen, 3-acetamidophenol and atorvastatin calcium) were observed in each compartment. It was concluded that the findings were consistent with the toxicity data in humans and animals. For example, doxorubicin has been shown to lead to a decrease in the frequency of cardiomyocytes. This is due to the toxicity caused by the metabolite of doxorubicin. When acetaminophen was applied to the system, there was a decrease in hepatocyte viability. This

Table 3. A snapshot of studies about multi-organ-on-a-chip systems.

\begin{tabular}{|c|c|c|}
\hline $\begin{array}{l}\text { Multi-Organ } \\
\text { Applications }\end{array}$ & Drugs and Applications & References \\
\hline $\begin{array}{l}\text { Liver } \\
\text { Heart } \\
\text { (incl. a heart-only } \\
\text { system) }\end{array}$ & $\begin{array}{l}\text { - The cardiotoxic response to terfenadine has been shown } \\
\text { in the system. } \\
\text { - Another previously discovered proprietary small drug } \\
\text { molecule that is transformed into a cardiotoxic metabolite } \\
\text { has also been tested in the heart:liver system. }\end{array}$ & $\begin{array}{l}\text { McAleer et al., } 2019 \\
\text { [109] }\end{array}$ \\
\hline $\begin{array}{l}\text { Liver } \\
\text { Intestine }\end{array}$ & $\begin{array}{l}\text { The model describes the characterization of } \\
\text { pharmacokinetic properties of acetaminophen. }\end{array}$ & $\begin{array}{c}\text { Marin et al., } 2019 \\
\text { [18] }\end{array}$ \\
\hline $\begin{array}{l}\text { Kidney } \\
\text { Intestine }\end{array}$ & $\begin{array}{l}\text { This intestine-kidney chip, containing co-culture of the } \\
\text { intestinal and glomerular endothelial cells, provided an } \\
\text { integrated, cost-effective platform for assessment of drug } \\
\text { absorption-related nephrotoxicity in vitro. Consistent with } \\
\text { clinical evidence, the nephrotoxicity of a selected drug } \\
\text { (digoxin) has been shown to be altered via absorption by } \\
\text { other drugs. }\end{array}$ & $\begin{array}{l}\text { Li et al., } 2017 \\
\quad[110]\end{array}$ \\
\hline $\begin{array}{l}\text { Liver } \\
\text { Intestine } \\
\text { Skin } \\
\text { Kidney }\end{array}$ & $\begin{array}{l}\text { The four-organ-chip system has been reported to provide } \\
\text { near-to- physiological fluid-to-tissue ratios. } \\
\text { This is the first approach in a microfluidic system, to } \\
\text { generate an absorption-distribution-metabolism-excretion } \\
\text { (ADME) profile and repeated-dose systemic toxicity testing } \\
\text { of drug candidates. }\end{array}$ & Maschmeyer et al., 2015 [17] \\
\hline $\begin{array}{l}\text { Liver } \\
\text { Skin }\end{array}$ & $\begin{array}{l}\text { The system supports two different culture modes: } \\
\text { - tissue exposed to the fluid flow, } \\
\text { - tissue shielded from underlying fluid flow by standard } \\
\text { Transwell }{ }^{\circledR} \text { cultures. } \\
\text { Liver micro-tissues has been shown to exert sensitivity at } \\
\text { different molecular levels to troglitazone. }\end{array}$ & $\begin{array}{l}\text { Wagner et al., } 2013 \\
\text { [111] }\end{array}$ \\
\hline $\begin{array}{l}\text { Liver } \\
\text { Intestine } \\
\text { (tumor) }\end{array}$ & $\begin{array}{l}\text { The system correctly assays the overall digestive properties } \\
\text { of oral anticancer agents (e.g., cyclophosphamide and } \\
\text { tegafur). } \\
\text { Anticancer activity and drug metabolism were tested. }\end{array}$ & $\begin{array}{l}\text { Imura et al., } 2012 \\
\text { [112] }\end{array}$ \\
\hline $\begin{array}{l}\text { Liver } \\
\text { Brain } \\
\text { (tumor) }\end{array}$ & $\begin{array}{l}\text { The cytotoxicity of anticancer drugs, including } \\
\text { temozolomide and ifosfamide, was tested. }\end{array}$ & $\begin{array}{l}\text { Ma et al., } 2012 \\
\text { [113] }\end{array}$ \\
\hline $\begin{array}{l}\text { Liver } \\
\text { Bone marrow } \\
\text { (tumor) }\end{array}$ & $\begin{array}{l}\text { Anticancer drug (e.g., 5-FU) was tested in a microfluidic } \\
\text { device based on a pharmacokinetics-pharmacodynamics } \\
\text { model connected by fluid channels to test drug toxicity. }\end{array}$ & $\begin{array}{l}\text { Sung et al., } 2010 \\
\text { [114] }\end{array}$ \\
\hline $\begin{array}{l}\text { Liver } \\
\text { Colon cancer } \\
\text { Bone marrow cell line }\end{array}$ & Anticancer effects of 5-FU and tegafur were tested. & $\begin{array}{l}\text { Sung and Shuler, } 2009 \\
\qquad[115]\end{array}$ \\
\hline
\end{tabular}


system appears as the first pump-free organ-on-a-chip that can reflect the body's response to drugs for 14-days [116]. The critical importance of bioactivation was illustrated in a study. Li et al. (2018) developed a liver-kidney chip capable of effectively evaluating drug metabolism in the liver and conducted a nephrotoxicity study on this device. The active substances used in the experiment were identified as nephrotoxic, leading to changes in cell viability, LDH leakage and permeability of kidney cells to large protein molecules after biotransformation in the liver. Nephrotoxic responses after hepatic metabolism observed in the liver-kidney chip were similar to physiological responses in the clinic [117].

In a different perspective, a multi-organ microfluidic platform was established to recapitulate the entire brain metastasis (BM) process, and it was applied to the BM pathology research, especially blood-brain barrier (BBB) extravasation [118]. With synergistic use of the chip and traditional models, the researchers demonstrated that Aldo-keto reductase family 1 B10 (AKR1B10) was significantly elevated in lung cancer BM; in addition, the value of AKR1B10 as a diagnostic serum biomarker for lung cancer patients suffering from BM could be demonstrated. The role and mechanisms of AKR1B10 in $\mathrm{BM}$ that it promotes the extravasation of cancer cells through the BBB were also evaluated.

Besides their potential use in drug R\&D, the microfluidic devices have been applied to detection or evaluation of other analytes including environmental pollutants, pesticides, and some toxins. Bovard et al. (2018) designed an acute and chronic toxicity study on a chip composed of lung and liver cells. The capacity of liver cells to metabolize and regulate their toxicity was assessed using aflatoxin B1 [107]. In a study by Jellali et al. (2018), the effects of two pesticides, namely DDT and permethrin on hepatocytes grown in biochips were investigated. Although their toxicity has been extensively studied, the molecular mechanisms, including the impact on liver where their detoxification occurs, and their metabolic effects are not clear. This study showed deterioration of time-dependent sugar/lipid homeostasis with DDT and permethrin. In addition, high doses of DDT have been shown to cause cell death, inflammatory response, and oxidative stress [119]. A recent application is a microfluidic paper-based analytical device with benzoquinonemediated $E$. coli respiration method, that is suitable for practical use due to its simple operation, low cost and portability. Similarly, the pesticide residues in vegetable juices have been detected [120]. An in vitro analytical platform has been developed to investigate neurotoxic snake venom proteins rapidly with microfluidic highresolution screening. In this device, 47 snake venoms were profiled using the acetylcholine binding protein to mimic the target of neurotoxic proteins, in particular nicotinic acetylcholine receptors [121].

As the development of nanomaterials increases, the nanotoxicologists face a major challenge in developing a model that can accurately mimic human physiology. In general, extrapolation of results from animal tests of nanomaterials is often a misrepresentation of clinical effects. In vitro experiments fail to control the exposure levels of nanomaterials and cannot take into account some physicochemical aspects, such as particle aggregation. Ashammakhi et al. (2020) have proposed that microphysiological systems, especially multiorgan-ona-chip systems, which can be specifically designed to test the systemic toxicity, can be of use to evaluate the toxicity of nanomaterials [122]. The potential of microfluidic systems is evaluated for nanotoxicity research in various experiments. For example, in neuron-like-PC12 cells cultured in microfluidic devices, cytotoxic effects of surface-modified quantum dots have been demonstrated [123].

As described earlier, specific challenges, such as the demand to restrict the absorption of small hydrophobic molecules on the PDMS platform, also can lead to production of systems that meet the criteria. For example, Hirama et al. (2019) have recently produced a glassbased organ-on-a-chip and obtained a more stable flow compared to PDMS platforms, limiting the absorption of small hydrophobic molecules, and increasing cell adhesion. It was concluded that this glass chip could be used in cell-based assays to test small hydrophobic molecules [63].

However, organ-on-a-chip systems have not yet been utilized to validate toxicity profiles for approval of drugs, as well as in the assessment of carcinogenicity and reproductive toxicity. Thus, the comprehensive validation of the chips for chronic toxicity testing will be necessary to use this technology. Further information on innovative designs on the main technologies (self-organized spherical 3D human organoids, microfabricated 3D human organ chips, and 3D bio-printed human organ constructs) to mimic key properties of human organs are reviewed in detail [124]. 
Last but not least, especially in the last decade, the number of studies that apply commercial organ-on-achip platforms have increased along with the establishment of dedicated companies such as Emulate, CN Bio, TissUse, Mimetas, Insphero, Ascendance Bio, Kirkstall, Hurel, Synvivo, Axosim, and Nortis. The non-redundant list of microfluidic companies is available at https://ufluidix.com/circle/microfluidic-companies/ and https:// www.fluidicmems.org/microfluidic-companies. As an example, for the evaluation of renal drug interactions with efflux transporters, Vriend et al. (2018) have used a platform suitable for medium to high-throughput screenings, consisting of 96 chips containing the most important renal drug transporters in an OrganoPlate ${ }^{\circledR}$ from Mimetas [11].

\section{DISCUSSION}

The rapid increase in the number of publications on microfluidic devices reflects the increasing interest of the scientific community. In this review, we provided a snapshot of the current applications in organ-on-a-chip systems combining 3D microstructures, multiple cells, and microfluidic connections, which were developed to mimic the desired organs as functional models in physiological micro-environments as a current application and highlighted for use in pharmacy, especially regarding examples in toxicology research.

The studies on this subject show that it can be possible to evaluate all organs of a human body, on-a-chip for toxicological and disease-related issues. The toxicological studies of multi-organ-on-a-chip systems will probably open a window to reveal some particular tissue-tissue interactions that can lead to particular mechanisms of toxicity. Regardless of the organ being imitated, the properties of tissue mainly depend on the source of the cells; thus, particular attention is crucial in the selection of the cell type according to the desired endpoint. These models are expected to provide in-depth understanding of the interactions between drugs and metabolites in organs in terms of efficacy and/or safety. Moreover, the multi-organ-on-a-chip systems can be more effectively used in ADME studies and provide an opportunity to improve the estimation of some properties of compounds in patients. The multi-organ-on-a-chip systems are expected to create a new paradigm for drug development by contributing to a better understanding of the dose-response relationships, the treatment failures in some patients or the detection of adverse reactions, supporting potential side effects and promoting the evaluation of pharmacokinetic/pharmacodynamic parameters.

Depending on the interactions between microfluidics, biosensors and tissue engineering; biomedical devices become more comprehensive and mimic the complex functions of diseased or damaged tissues and organs. Despite relatively limited biomedical applications of microfluidics in vitro or ex vivo, we may propose that in the near future microfluidic platforms will probably be more widely used in diagnostic and clinical settings such as the capturing of tumor cells in circulation.

Developing microfluidics from simple systems to complex systems, being part of groundbreaking and futuristic ideas, it is likely that studies on the chip will play a role in improving body on a chip development approaches [125]. The multidisciplinary feature of microfluidics requires continued coordination between engineering, physical, and biological sciences to achieve good efficiency [41]. As a result of the development of new production processes, organ-on-a-chip and multiorgan-on-a-chip, which are associated with a potential future reduction in manufacturing costs, will probably become efficient and provide standardized platforms for toxicity studies [49].

\section{FUTURE PROSPECTS}

The ultimate aim of the researchers is to switch from an organ-on-a-chip to a human-on-a-chip system. Humanon-a-chip system can combine the relationships of organs, blood distribution, and blood flow according to human physiology. These systems can simulate human metabolism, including the biotransformation of a drug, its therapeutic and toxic effects [126]. In future approaches; progress is expected to be made in areas such as developing new designs for micro systems, increasing research on organ systems on-chip, and identifying new cell resources and materials to support adaptation to medical needs in humans [127]. When combined with cells or biopsies collected from patients, these models can also be used as a tool for personalized-drug screening [125].

Considering the social impact of organ-on-a-chip technology is crucial for its future development. While existing technologies are still too expensive for widespread use, new steps are being taken. Downward price pres- 
sure will lead to lower prices. Conventional in vitro and in vivo models will be replaced by these new preclinical technologies. The commercial interest in organ-ona-chip technology is growing, and the market for this technology is estimated to reach six billion dollars in about 5 years [128].

The development of an efficient production process for the commercialization of chips is a situation that must be overcome. It is emphasized that wide-ranging cooperation between pharmaceutical companies can be effective in this issue [129]. Apparently, there is a need for standardization of models for each of the organs to be imitated for extensive organ-on-a-chip and multiorgan-on-a-chip applications. As microfluidic systems become readily available, researchers will not need to develop a specially crafted laboratory for each application. This will increase the industrial development of microfluidics [53].

In the coming years, we will probably discuss the use of microfluidic systems in many fields, such as the context of precision medicine; indeed, the "personalized organs-on-chips", designed to reflect the individual's physiology, may provide an integral solution to personalized treatment and prevention strategies [130].

\section{References}

1. S.N. Bhatia, D.E. Ingber, Microfluidic organs-on-chips, Nat Biotechnol. 32 (2014) 760-772.

2. M.B. Esch, A.S.T. Smith, J.M. Prot, C. Oleaga, J.J. Hickman, M.L. Shuler, How multi-organ microdevices can help foster drug development, Adv. Drug Deliv. Rev. 69-70 (2014) 158169

3. C.M. Sakolish, M.B. Esch, J.J. Hickman, M.L. Shuler, G.J. Mahler, Modeling barrier tissues in vitro: Methods, achievements, and challenges, EBioMedicine. 5 (2016) 3039.

4. J.D. Caplin, N.G. Granados, M.R. James, R. Montazami, N. Hashemi, Microfluidic organ-on-a-chip technology for advancement of drug development and toxicology, Adv. Healthc. Mater. 4 (2015) 1426-1450.

5. R. Greek, A. Menache, Systematic reviews of animal models: Methodology versus epistemology, Int. J. Med. Sci. 10 (2013) 206-221.

6. A. Skardal, T. Shupe, A. Atala, Organoid-on-a-chip and bodyon-a-chip systems for drug screening and disease modeling, Drug Discov. Today. 21 (2016) 1399-1411.

7. L. Ewart, K. Fabre, A. Chakilam, Y. Dragan, D.B. Duignan, J. Eswaraka, J. Gan, P. Guzzie-Peck, M. Otieno, C.G. Jeong, D.A. Keller, S.M. de Morais, J.A. Phillips, W. Proctor, R. Sura, T. Van Vleet, D. Watson, Y. Will, D. Tagle, B. Berridge, Navigating tissue chips from development to dissemination: A pharmaceutical industry perspective, Exp. Biol. Med. 242 (2017) 1579-1585.
8. S. Ishida, Organs-on-a-chip: Current applications and consideration points for in vitro ADME-Tox studies, Drug Metab. Pharmacokinet. 33 (2018) 49-54.

9. H. Kimura, Y. Sakai, T. Fujii, Organ/body-on-a-chip based on microfluidic technology for drug discovery, Drug Metab. Pharmacokinet. 33 (2018) 43-48.

10. S. Lu, F. Cuzzucoli, J. Jiang, L.G. Liang, Y. Wang, M. Kong, X. Zhao, W. Cui, J. Li, S. Wang, Development of a biomimetic liver tumor-on-a-chip model based on decellularized liver matrix for toxicity testing, Lab Chip. 18 (2018) 3379-3392.

11. J. Vriend, T.T.G. Nieskens, M.K. Vormann, B.T. van den Berge, A. van den Heuvel, F.G.M. Russel, L. Suter-Dick, H.L. Lanz, P. Vulto, R. Masereeuw, M.J. Wilmer, Screening of drugtransporter interactions in a $3 \mathrm{D}$ microfluidic renal proximal tubule on a chip, AAPS J. 20 (2018) 87.

12. M.K. Vormann, L. Gijzen, S. Hutter, L. Boot, A. Nicolas, A. van den Heuvel, J. Vriend, C.P. Ng, T.T.G. Nieskens, V. van Duinen, B. de Wagenaar, R. Masereeuw, L. Suter-Dick, S.J. Trietsch, M. Wilmer, J. Joore, P. Vulto, H.L. Lanz, Nephrotoxicity and kidney transport assessment on 3D perfused proximal tubules, AAPS J. 20 (2018) 90.

13. W. Wang, Y. Yan, C.W. Li, H.M. Xia, S.S. Chao, D.Y. Wang, Z.P. Wang, Live human nasal epithelial cells (hNECs) on chip for in vitro testing of gaseous formaldehyde toxicity via airway delivery, Lab Chip. 14 (2014) 677-680.

14. L.M. Griep, F. Wolbers, B. de Wagenaar, P.M. ter Braak, B.B. Weksler, I.A. Romero, P.O. Couraud, I. Vermes, A.D. van der Meer, A. van den Berg, BBB on chip: microfluidic platform to mechanically and biochemically modulate blood-brain barrier function, Biomed. Microdevices. 15 (2013) 145-150.

15. A. Grosberg, P.W. Alford, M.L. McCain, K.K. Parker, Ensembles of engineered cardiac tissues for physiological and pharmacological study: Heart on a chip, Lab Chip. 11 (2011) 4165-4173.

16. G. Khanal, K. Chung, X. Solis-Wever, B. Johnson, D. Pappas, Ischemia/reperfusion injury of primary porcine cardiomyocytes in a low-shear microfluidic culture and analysis device, Analyst. 136 (2011) 3519-3526.

17. I. Maschmeyer, A.K. Lorenz, K. Schimek, T. Hasenberg, A.P. Ramme, J. Hübner, M. Lindner, C. Drewell, S. Bauer, A. Thomas, N.S. Sambo, F. Sonntag, R. Lauster, U. Marx, A four-organ-chip for interconnected long-term co-culture of human intestine, liver, skin and kidney equivalents, Lab Chip. 15 (2015) 2688-2699.

18. T.M. Marin, N. de Carvalho Indolfo, S.A. Rocco, F.L. Basei, M. de Carvalho, K. de Almeida Gonçalves, E. Pagani, Acetaminophen absorption and metabolism in an intestine/ liver microphysiological system, Chem. Biol. Interact. 299 (2019) 59-76.

19. D. Huh, D.C. Leslie, B.D. Matthews, J.P. Fraser, S. Jurek, G.A. Hamilton, K.S. Thorneloe, M.A. McAlexander, D.E. Ingber, A human disease model of drug toxicity-induced pulmonary edema in a lung-on-a-chip microdevice, Sci. Transl. Med. 4 (2012) 159ra-147.

20. G.M. Whitesides, The origins and the future of microfluidics, Nature. 442 (2006) 368-373.

21. D. Mark, S. Haeberle, G. Roth, F. Von Stetten, R. Zengerle, Microfluidic lab-on-a-chip platforms: Requirements, characteristics and applications, Chem. Soc. Rev. 39 (2010) $1153-1182$.

22. Y. Li, S. Wang, R. Huang, Z. Huang, B. Hu, W. Zheng, G. Yang, X. Jiang, Evaluation of the effect of the structure of bacterial cellulose on full thickness skin wound repair on a microfluidic chip, Biomacromolecules. 16 (2015) 780-789. 
23. R.R.G. Soares, D. Ramadas, V. Chu, M.R. Aires-Barros, J.P. Conde, A.S. Viana, A.C. Cascalheira, An ultrarapid and regenerable microfluidic immunoassay coupled with integrated photosensors for point-of-use detection of ochratoxin A, Sensors Actuators B Chem. 235 (2016) 554562

24. F.E. Yigit, i.i. Bosgelmez, Emerging potential of microfluidic chips in the field of forensics. $3^{\text {rd }}$ Reg. TIAFT Meet. Turkey, 18-20 Oct. 2018, 175-176.

25. W. Zhou, J. Le, Y. Chen, Y. Cai, Z. Hong, Y. Chai, Recent advances in microfluidic devices for bacteria and fungus research, TrAC Trends Anal. Chem. 112 (2019) 175-195.

26. K. İçöz, O. Mzava, Detection of proteins using nano magnetic particle accumulation-based signal amplification, Appl. Sci. 6 (2016) 394

27. W. Huang, C.L. Chang, N.D. Brault, O. Gur, Z. Wang, S.I. Jalal, P.S. Low, T.L. Ratliff, R. Pili, C.A. Savran, Separation and dual detection of prostate cancer cells and protein biomarkers using a microchip device, Lab Chip. 17 (2017) 415-428.

28. D. Pekin, Y. Skhiri, J.C. Baret, D. Le Corre, L. Mazutis, C. Ben Salem, F. Millot, A. El Harrak, J.B. Hutchison, J.W. Larson, D.R. Link, P. Laurent-Puig, A.D. Griffiths, V. Taly, Quantitative and sensitive detection of rare mutations using droplet-based microfluidics, Lab Chip. 11 (2011) 2156-2166.

29. E.K. Sackmann, A.L. Fulton, D.J. Beebe, The present and future role of microfluidics in biomedical research, Nature. 507 (2014) 181-189.

30. X. Zhang, S.J. Haswell, Materials matter in microfluidic devices, MRS Bull. 31 (2006) 95-99.

31. X. Hou, Y.S. Zhang, G.T. Santiago, M.M. Alvarez, J. Ribas, S.J. Jonas, P.S. Weiss, A.M. Andrews, J. Aizenberg, A Khademhosseini, Interplay between materials and microfluidics, Nat. Rev. Mater. 2 (2017) 17016.

32. E. Berthier, E.W.K. Young, D. Beebe, Engineers are from PDMS-land, Biologists are from Polystyrenia, Lab Chip. 12 (2012) 1224-1237.

33. S. Ahadian, R. Civitarese, D. Bannerman, M.H. Mohammadi, R. Lu, E. Wang, L. Davenport-Huyer, B. Lai, B. Zhang, Y. Zhao, S. Mandla, A. Korolj, M. Radisic, Organ-on-a-chip platforms: A convergence of advanced materials, cells, and microscale technologies, Adv. Healthc. Mater. 7 (2018) 1700506.

34. B. Zhang, A. Korolj, B.F.L. Lai, M. Radisic, Advances in organon-a-chip engineering, Nat. Rev. Mater. 3 (2018) 257-278.

35. J.B. Nielsen, R.L. Hanson, H.M. Almughamsi, C. Pang, T.R. Fish, A.T. Woolley, Microfluidics: Innovations in materials and their fabrication and functionalization, Anal. Chem. 92 (2020) 150-168.

36. K. Ren, J. Zhou, H. Wu, Materials for microfluidic chip fabrication, Acc. Chem. Res. 46 (2013) 2396-2406.

37. X. Liu, B. Lin, Materials Used in Microfluidic Devices, in: Encycl. Microfluid. Nanofluidics, Springer US, Boston, MA 2014: pp. 1-5.

38. C.W. Tsao, Polymer Microfluidics: Simple, low-cost fabrication process bridging academic lab research to commercialized production, Micromachines. 7 (2016) 225.

39. H. Becker, L.E. Locascio, Polymer microfluidic devices, Talanta. 56 (2002) 267-287.

40. S.A. Soper, A.C. Henry, B. Vaidya, M. Galloway, M. Wabuyele, R.L. McCarley, Surface modification of polymer-based microfluidic devices, Anal. Chim. Acta. 470 (2002) 87-99.

41. P.N. Nge, C.I. Rogers, A.T. Woolley, Advances in microfluidic materials, functions, integration, and applications, Chem Rev. 113 (2013) 2550-2583.
42. I. Wong, C.M. Ho, Surface molecular property modifications for poly(dimethylsiloxane) (PDMS) based microfluidic devices, Microfluid. Nanofluidics. 7 (2009) 291-306.

43. K.R. King, C.C.J. Wang, M.R. Kaazempur-Mofrad, J.P. Vacanti, J.T. Borenstein, Biodegradable microfluidics., Adv. Mater. 16 (2004) 2007-2012.

44. I.R.G. Ogilvie, V.J. Sieben, C.F.A. Floquet, R. Zmijan, M.C. Mowlem, H. Morgan, Reduction of surface roughness for optical quality microfluidic devices in PMMA and COC, J. Micromechanics Microengineering. 20 (2010) 065016.

45. M.M. Faghih, M.K. Sharp, Solvent-based bonding of PMMAPMMA for microfluidic applications, Microsyst. Technol. 25 (2019) 3547-3558.

46. G.M. Whitesides, E. Ostuni, S. Takayama, X. Jiang, D.E. Ingber, Soft lithography in biology and biochemistry, Annu. Rev. Biomed. Eng. 3 (2001) 335-373.

47. T. Thorsen, S. Maerkl, S. Quake, Microfluidic large-scale integration, Science 298 (2002) 580-584.

48. M.C. Bélanger, Y. Marois, Hemocompatibility, biocompatibility, inflammatory and in vivo studies of primary reference materials low-density polyethylene and polydimethylsiloxane: A review, J. Biomed. Mater. Res. 58 (2001) 467-477.

49. D. Bovard, A. Iskandar, K. Luettich, J. Hoeng, M.C. Peitsch, Organs-on-a-chip: A new paradigm for toxicological assessment and preclinical drug development, Toxicol. Res. Appl. 1 (2017) 1-16.

50. M.W. Toepke, D.J. Beebe, PDMS absorption of small molecules and consequences in microfluidic applications, Lab Chip. 6 (2006) 1484-1486.

51. J.D. Wang, N.J. Douville, S. Takayama, M. ElSayed, Quantitative analysis of molecular absorption into PDMS microfluidic channels, Ann. Biomed. Eng. 40 (2012) 18621873.

52. B.J. van Meer, H. de Vries, K.S.A. Firth, J. van Weerd, L.G.J. Tertoolen, H.B.J. Karperien, P. Jonkheijm, C. Denning, A.P. IJzerman, C.L. Mummery, Small molecule absorption by PDMS in the context of drug response bioassays, Biochem. Biophys. Res. Commun. 482 (2017) 323-328.

53. A. Alrifaiy, O.A. Lindahl, K. Ramser, Polymer-based microfluidic devices for pharmacy, biology and tissue engineering, Polymers (Basel). 4 (2012) 1349-1398.

54. S. Halldorsson, E. Lucumi, R. Gómez-Sjöberg, R.M.T. Fleming, Advantages and challenges of microfluidic cell culture in polydimethylsiloxane devices, Biosens. Bioelectron. 63 (2015) 218-231.

55. D.J. Guckenberger, T.E. de Groot, A.M.D. Wan, D.J. Beebe, Micromilling: a method for ultra-rapid prototyping of plastic microfluidic devices, Lab Chip. 15 (2015) 2364-2378.

56. C. Matellan, A.E. del Río Hernández, Cost-effective rapid prototyping and assembly of poly(methyl methacrylate) microfluidic devices, Sci. Rep. 8 (2018) 6971.

57. E. Gencturk, S. Mutlu, K.O. Ulgen, Advances in microfluidic devices made from thermoplastics used in cell biology and analyses, Biomicrofluidics. 11 (2017) 051502.

58. S. Moon, U.A. Gurkan, J. Blander, W.W. Fawzi, S. Aboud, F. Mugusi, D.R. Kuritzkes, U. Demirci, Enumeration of CD4+ T-cells using a portable microchip count platform in tanzanian hiv-infected patients, PLoS One. 6 (2011) e21409.

59. J.H. Day, T.M. Nicholson, X. Su, T.L. van Neel, I. Clinton, A. Kothandapani, J. Lee, M.H. Greenberg, J.K. Amory, T.J. Walsh, C.H. Muller, O.E. Franco, C.R. Jefcoate, S.E. Crawford, J.S. Jorgensen, A.B. Theberge, Injection molded open microfluidic well plate inserts for user-friendly coculture and microscopy, Lab Chip. 20 (2020) 107-119. 
60. J.C. Krebs, Y. Alapan, B.A. Dennstedt, G.D. Wera, U.A. Gurkan, Microfluidic processing of synovial fluid for cytological analysis, Biomed. Microdevices. 19 (2017) 20.

61. M. Kim, Y. Alapan, A. Adhikari, J.A. Little, U.A. Gurkan Hypoxia-enhanced adhesion of red blood cells in microscale flow, Microcirculation 24 (2017) e12374.

62. Y. Alapan, M.N. Hasan, R. Shen, U.A. Gurkan, Threedimensional printing based hybrid manufacturing of microfluidic devices, J. Nanotechnol. Eng. Med. 6(2) (2015) 021007.

63. H. Hirama, T. Satoh, S. Sugiura, K. Shin, R. Onuki-Nagasaki, T. Kanamori, T. Inoue, Glass-based organ-on-a-chip device for restricting small molecular absorption, J. Biosci. Bioeng. 127 (2019) 641-646.

64. A. Naderi, N. Bhattacharjee, A. Folch, Digital manufacturing for microfluidics, Annu. Rev. Biomed. Eng. 21 (2019) 325364

65. J.U. Lind, T.A. Busbee, A.D. Valentine, F.S. Pasqualini, H. Yuan, M. Yadid, S.J. Park, A. Kotikian, A.P. Nesmith, P.H Campbell, J.J. Vlassak, J.A. Lewis, K.K. Parker, Instrumented cardiac microphysiological devices via multimaterial threedimensional printing, Nat. Mater. 16 (2017) 303-308.

66. H.G. Yi, H. Lee, D.W. Cho, 3D Printing of organs-on-chips, Bioengineering. 4 (2017) 10.

67. F. Kotz, P. Risch, K. Arnold, S. Sevim, J. Puigmartí-Luis, A. Quick, M. Thiel, A. Hrynevich, P.D. Dalton, D. Helmer, B.E. Rapp, Fabrication of arbitrary three-dimensional suspended hollow microstructures in transparent fused silica glass, Nat. Commun. 10 (2019) 1439.

68. Y. Alapan, K. Icoz, U.A. Gurkan, Micro- and nanodevices integrated with biomolecular probes, Biotechnol. Adv. 33 (2015) 1727-1743

69. H. Liu, Y. Wang, K. Cui, Y. Guo, X. Zhang, J. Qin, Advances in hydrogels in organoids and organs-on-a-chip, Adv. Mater (2019) e1902042.

70. M. Kaljurand, Paper microzones as a route to greener analytical chemistry, Curr. Opin. Green Sustain. Chem. 19 (2019) 15-18.

71. Y. Ai, F. Zhang, C. Wang, R. Xie, Q. Liang, Recent progress in lab-on-a-chip for pharmaceutical analysis and pharmacological/toxicological test, TrAC Trends Anal. Chem. 117 (2019) 215-230.

72. S.C. Bell, R.D. Hanes, A microfluidic device for presumptive testing of controlled substances, J. Forensic Sci. 52 (2007) 884-888

73. P.T. Garcia, E.F.M. Gabriel, G.S. Pessôa, J.C. Santos Júnior, P.C. Mollo Filho, R.B.F. Guidugli, N.F. Höehr, M.A.Z. Arruda, W.K.T. Coltro, Paper-based microfluidic devices on the crime scene: A simple tool for rapid estimation of post-mortem interval using vitreous humour, Anal. Chim. Acta. 974 (2017) 69-74.

74. R.L. Cromartie, A. Wardlow, G. Duncan, B.R. McCord, Development of a microfluidic device ( $\mu$ PADs) for forensic serological analysis, Anal. Methods. 11 (2019) 587-595.

75. S. Loiodice, A. Nogueira da Costa, F. Atienzar, Current trends in in silico, in vitro toxicology, and safety biomarkers in early drug development, Drug Chem. Toxicol. 42 (2019) 113-121.

76. A. Balijepalli, V. Sivaramakrishan, Organs-on-chips: research and commercial perspectives, Drug Discov. Today. 22 (2017) 397-403.

77. K.A. Fitzgerald, M. Malhotra, C.M. Curtin, F.J. O' Brien, C.M $\mathrm{O}^{\prime}$ Driscoll, Life in 3D is never flat: 3D models to optimise drug delivery, J. Control. Release. 215 (2015) 39-54.

78. B.M. Baker, C.S. Chen, Deconstructing the third dimension how 3D culture microenvironments alter cellular cues, J. Cell Sci. 125 (2012) 3015-3024.
79. D. Loessner, C. Meinert, E. Kaemmerer, L.C. Martine, K. Yue, P.A. Levett, T.J. Klein, F.P.W. Melchels, A. Khademhosseini, D.W. Hutmacher, Functionalization, preparation and use of cell-laden gelatin methacryloyl-based hydrogels as modular tissue culture platforms, Nat. Protoc. 11 (2016) 727-746.

80. D. Antoni, H. Burckel, E. Josset, G. Noel, Three-dimensional cell culture: A breakthrough in vivo, Int. J. Mol. Sci. 16 (2015) 5517-5527.

81. X. Ma, J. Liu, W. Zhu, M. Tang, N. Lawrence, C. Yu, M. Gou, S. Chen, 3D bioprinting of functional tissue models for personalized drug screening and in vitro disease modeling, Adv. Drug Deliv. Rev. 132 (2018) 235-251.

82. H.J. Kim, D.E. Ingber, Gut-on-a-Chip microenvironment induces human intestinal cells to undergo villus differentiation, Integr. Biol. 5 (2013) 1130-1140.

83. N. Gupta, J.R. Liu, B. Patel, D.E. Solomon, B. Vaidya, V. Gupta, Microfluidics-based 3D cell culture models: Utility in novel drug discovery and delivery research, Bioeng. Transl. Med. 1 (2016) 63-81.

84. B. Kwak, A. Ozcelikkale, C.S. Shin, K. Park, B. Han, Simulation of complex transport of nanoparticles around a tumor using tumor-microenvironment-on-chip, J. Control. Release. 194 (2014) 157-167.

85. A. Zuchowska, K. Marciniak, U. Bazylinska, E. Jastrzebska, K.A. Wilk, Z. Brzozka, Different action of nanoencapsulated meso-tetraphenylporphyrin in breast spheroid co-culture and mono-culture under microfluidic conditions, Sensors Actuators B Chem. 275 (2018) 69-77.

86. A. Zuchowska, E. Jastrzebska, M. Chudy, A. Dybko, Z. Brzozka, 3D lung spheroid cultures for evaluation of photodynamic therapy (PDT) procedures in microfluidic Lab-on-a-Chip system, Anal. Chim. Acta. 990 (2017) 110-120.

87. Y.S. Zhang, J. Aleman, S.R. Shin, T. Kilic, D. Kim, S.A. Mousavi Shaegh, S. Massa, R. Riahi, S. Chae, N. Hu, H. Avci, W. Zhang, A. Silvestri, A. Sanati Nezhad, A. Manbohi, F. De Ferrari, A. Polini, G. Calzone, N. Shaikh, P. Alerasool, E. Budina, J. Kang, N. Bhise, J. Ribas, A. Pourmand, A. Skardal, T. Shupe, C.E. Bishop, M.R. Dokmeci, A. Atala, A. Khademhosseini, Multisensor-integrated organs-on-chips platform for automated and continual in situ monitoring of organoid behaviors, Proc. Natl. Acad. Sci. 114 (2017) E2293-E2302.

88. Y.A. Jodat, M.G. Kang, K. Kiaee, G.J. Kim, A.F.H. Martinez, A. Rosenkranz, H. Bae, S.R. Shin, Human-derived organ-on-achip for personalized drug development, Curr. Pharm. Des. 24 (2019) 5471-5486.

89. C.H. Beckwitt, A.M. Clark, S. Wheeler, D.L. Taylor, D.B. Stolz, L. Griffith, A. Wells, Liver 'organ on a chip,' Exp. Cell Res. 363 (2018) 15-25.

90. G.J. Mahler, M.B. Esch, R.P. Glahn, M.L. Shuler, Characterization of a gastrointestinal tract microscale cell culture analog used to predict drug toxicity, Biotechnol. Bioeng. 104 (2009) 193-205.

91. V.M. Lauschke, D.F.G. Hendriks, C.C. Bell, T.B. Andersson, M. Ingelman-Sundberg, Novel 3D culture systems for studies of human liver function and assessments of the hepatotoxicity of drugs and drug candidates, Chem. Res. Toxicol. 29 (2016) 1936-1955.

92. J. Dai, M. Hamon, S. Jambovane, Microfluidics for antibiotic susceptibility and toxicity testing, Bioengineering. 3 (2016) 25.

93. C.Y. Li, K.R. Stevens, R.E. Schwartz, B.S. Alejandro, J.H. Huang, S.N. Bhatia, Micropatterned cell-cell interactions enable functional encapsulation of primary hepatocytes in hydrogel microtissues, Tissue Eng. Part A. 20 (2014) 2200-2212. 
94. L. Shintu, R. Baudoin, V. Navratil, J.M. Prot, C. Pontoizeau, M Defernez, B.J. Blaise, C. Domange, A.R. Péry, P. Toulhoat, C. Legallais, C. Brochot, E. Leclerc, M.E. Dumas, Metabolomics on-a-chip and predictive systems toxicology in microfluidic bioartificial organs, Anal. Chem. 84 (2012) 1840-1848.

95. S.M. Hattersley, J. Greenman, S.J. Haswell, Study of ethanol induced toxicity in liver explants using microfluidic devices, Biomed. Microdevices. 13 (2011) 1005-1014.

96. P.M. van Midwoud, M.T. Merema, E. Verpoorte, G.M.M. Groothuis, A microfluidic approach for in vitro assessment of interorgan interactions in drug metabolism using intestinal and liver slices, Lab Chip. 10 (2010) 2778-2786.

97. Y.C. Toh, T.C. Lim, D. Tai, G. Xiao, D. van Noort, H. Yu, A microfluidic 3D hepatocyte chip for drug toxicity testing, Lab Chip. 9 (2009) 2026-2035.

98. K.J. Jang, A.P. Mehr, G.A. Hamilton, L.A. McPartlin, S. Chung, K.Y. Suh, D.E. Ingber, Human kidney proximal tubule-ona-chip for drug transport and nephrotoxicity assessment, Integr. Biol. 5 (2013) 1119-1129.

99. R. Baudoin, L. Griscom, M. Monge, C. Legallais, E. Leclerc, Development of a renal microchip for in vitro distal tubule models, Biotechnol. Prog. 23 (2007) 1245-1253.

100. J.H. Yeon, D. Na, K. Choi, S.W. Ryu, C. Choi, J.K. Park, Reliable permeability assay system in a microfluidic device mimicking cerebral vasculatures, Biomed. Microdevices. 14 (2012) 1141-1148.

101. G. Shayan, Y.S. Choi, E. V. Shusta, M.L. Shuler, K.H. Lee, Murine in vitro model of the blood-brain barrier for evaluating drug transport, Eur. J. Pharm. Sci. 42 (2011) 148-155.

102. A. Agarwal, J.A. Goss, A. Cho, M.L. McCain, K.K. Parker, Microfluidic heart on a chip for higher throughput pharmacological studies, Lab Chip. 13 (2013) 3599-3608.

103. W. Siyan, Y. Feng, Z. Lichuan, W. Jiarui, W. Yingyan, J. Li, L. Bingcheng, W. Qi, Application of microfluidic gradient chip in the analysis of lung cancer chemotherapy resistance, J. Pharm. Biomed. Anal. 49 (2009) 806-810.

104. J.H. Yeon, J.K. Park, Drug permeability assay using microholetrapped cells in a microfluidic device, Anal. Chem. 81 (2009) 1944-1951.

105. D. Huh, A human breathing lung-on-a-chip, Ann. Am. Thorac. Soc. 12 (2015) S42-S44.

106. P.S. Hiemstra, G. Grootaers, A.M. van der Does, C.A.M. Krul, I.M. Kooter, Human lung epithelial cell cultures for analysis of inhaled toxicants: Lessons learned and future directions, Toxicol. Vitr. 47 (2018) 137-146

107. D. Bovard, A. Sandoz, K. Luettich, S. Frentzel, A. Iskandar, D. Marescotti, K. Trivedi, E. Guedj, Q. Dutertre, M.C. Peitsch, J. Hoeng, A lung/liver-on-a-chip platform for acute and chronic toxicity studies, Lab Chip. 18 (2018) 3814-3829.

108. J.H. Sung, Y.I. Wang, N. Narasimhan Sriram, M. Jackson, C. Long, J.J. Hickman, M.L. Shuler, Recent advances in body-ona-chip systems, Anal. Chem. 91 (2019) 330-351.

109. C.W. McAleer, A. Pointon, C.J. Long, R.L. Brighton, B.D. Wilkin L.R. Bridges, N. Narasimhan Sriram, K. Fabre, R. McDougall, V.P. Muse, J.T. Mettetal, A. Srivastava, D. Williams, M.T. Schnepper, J.L. Roles, M.L. Shuler, J.J. Hickman, L. Ewart, On the potential of in vitro organ-chip models to define temporal pharmacokinetic-pharmacodynamic relationships, Sci. Rep. 9 (2019) 9619.

110. Z. Li, W. Su, Y. Zhu, T. Tao, D. Li, X. Peng, J. Qin, Drug absorption related nephrotoxicity assessment on an intestine-kidney chip, Biomicrofluidics. 11 (2017) 034114
111. I. Wagner, E.M. Materne, S. Brincker, U. Süßbier, C. Frädrich, M. Busek, F. Sonntag, D.A. Sakharov, E. V. Trushkin, A.G. Tonevitsky, R. Lauster, U. Marx, A dynamic multi-organchip for long-term cultivation and substance testing proven by 3D human liver and skin tissue co-culture, Lab Chip. 13 (2013) 3538-3547.

112. Y. Imura, E. Yoshimura, K. Sato, Micro total bioassay system for oral drugs: Evaluation of gastrointestinal degradation, intestinal absorption, hepatic metabolism, and bioactivity, Anal. Sci. 28 (2012) 197-199.

113. L. Ma, J. Barker, C. Zhou, W. Li, J. Zhang, B. Lin, G. Foltz, J. Küblbeck, P. Honkakoski, Towards personalized medicine with a three-dimensional micro-scale perfusion-based two-chamber tissue model system, Biomaterials. 33 (2012) 4353-4361.

114. J.H. Sung, C. Kam, M.L. Shuler, A microfluidic device for a pharmacokinetic-pharmacodynamic (PK-PD) model on a chip, Lab Chip. 10 (2010) 446-455.

115. J.H. Sung, M.L. Shuler, A micro cell culture analog ( $\mu C C A)$ with 3-D hydrogel culture of multiple cell lines to assess metabolism-dependent cytotoxicity of anti-cancer drugs, Lab Chip. 9 (2009) 1385-1394.

116. C. Oleaga, C. Bernabini, A.S.T. Smith, B. Srinivasan, M. Jackson, W. McLamb, V. Platt, R. Bridges, Y. Cai, N. Santhanam, B. Berry, S. Najjar, N. Akanda, X. Guo, C. Martin, G. Ekman, M.B. Esch, J. Langer, G. Ouedraogo, J. Cotovio, L. Breton, M.L. Shuler, J.J. Hickman, Multi-Organ toxicity demonstration in a functional human in vitro system composed of four organs, Sci. Rep. 6 (2016) 20030.

117. Z. Li, L. Jiang, Y. Zhu, W. Su, C. Xu, T. Tao, Y. Shi, J. Qin, Assessment of hepatic metabolism-dependent nephrotoxicity on an organs-on-a-chip microdevice, Toxicol. Vitr. 46 (2018) 1-8.

118. W. Liu, J. Song, X. Du, Y. Zhou, Y. Li, R. Li, L. Lyu, Y. He, J. Hao, J. Ben, W. Wang, H. Shi, Q. Wang, AKR1B10 (Aldo-keto reductase family $1 \mathrm{~B} 10$ ) promotes brain metastasis of lung cancer cells in a multi-organ microfluidic chip model, Acta Biomater. 91 (2019) 195-208.

119. R. Jellali, P. Zeller, F. Gilard, A. Legendre, M.J. Fleury, S. Jacques, G. Tcherkez, E. Leclerc, Effects of DDT and permethrin on rat hepatocytes cultivated in microfluidic biochips: Metabolomics and gene expression study, Environ. Toxicol. Pharmacol. 59 (2018) 1-12.

120. J. Zhang, Z. Yang, Q. Liu, H. Liang, Electrochemical biotoxicity detection on a microfluidic paper-based analytical device via cellular respiratory inhibition, Talanta. 202 (2019) 384-391.

121. J. Slagboom, R.A. Otvos, F.C. Cardoso, J. Iyer, J.C. Visser, B.R. van Doodewaerd, R.J.R. McCleary, W.M.A. Niessen, G.W. Somsen, R.J. Lewis, R.M. Kini, A.B. Smit, N.R. Casewell, J. Kool, Neurotoxicity fingerprinting of venoms using on-line microfluidic AChBP profiling, Toxicon. 148 (2018) 213-222.

122. N. Ashammakhi, M.A. Darabi, B. Çelebi-Saltik, R. Tutar, M.C. Hartel, J. Lee, S.M. Hussein, M.J. Goudie, M.B. Cornelius, M.R. Dokmeci, A. Khademhosseini, Microphysiological systems: Next generation systems for assessing toxicity and therapeutic effects of nanomaterials, Small Methods. 4 (2020) 1900589.

123. S.K. Mahto, T.H. Yoon, S.W. Rhee, Cytotoxic effects of surface-modified quantum dots on neuron-like PC12 cells cultured inside microfluidic devices, BioChip J. 4 (2010) 82-88.

124. J. Park, I. Wetzel, D. Dréau, H. Cho, 3D Miniaturization of human organs for drug discovery, Adv. Healthc. Mater. 7 (2018) 1700551 
125. A. Perestrelo, A. Águas, A. Rainer, G. Forte, Microfluidic organ/body-on-a-chip devices at the convergence of biology and microengineering, Sensors. 15 (2015) 31142-31170.

126. G.J. Mahler, M.B. Esch, T. Stokol, J.J. Hickman, M.L. Shuler, Body-on-a-chip systems for animal-free toxicity testing, Altern. Lab. Anim. 44 (2016) 469-478

127. F. Zheng, F. Fu, Y. Cheng, C. Wang, Y. Zhao, Z. Gu, Organon-a-chip systems: Microengineering to biomimic living systems, Small. 12 (2016) 2253-2282.

128. L.H.M. van de Burgwal, P. van Dorst, H. Viëtor, R. Luttge, E. Claassen, Hybrid business models for 'Organ-on-a-Chip' technology: The best of both worlds, PharmaNutrition. 6 (2018) 55-63.
129. T. Kanamori, S. Sugiura, Y. Sakai, Technical aspects of microphysiological systems (MPS) as a promising wet human- in-vivo simulator, Drug Metab. Pharmacokinet. 33 (2018) 40-42.

130. A. van den Berg, C.L. Mummery, R. Passier, A.D. van der Meer, Personalised organs-on-chips: functional testing for precision medicine, Lab Chip. 19 (2019) 198-205. 